\title{
Biosynthesis of morphine in the animal kingdom
}

\section{H.W. Kosterlitz}

Two years ago, I wrote a News and Views article $^{1}$ entitled "Has morphine a physiological function in the animal kingdom?". New data, reported by Charles Weitz, Kym Faull and Avram Goldstein in their paper on page 674 of this issue ${ }^{2}$, provide evidence that may answer this question.

When I wrote my previous article, it was generally considered that the endogenous opioids in animal tissues are fragments of the large peptide precursors pro-opiocortin, pro-enkephalin and prodynorphin, whereas the non-peptide morphine is found in plants such as the poppy (Papaver somniferum). But about three years ago, Spector and colleagues showed that immunoreactive morphine is present in low concentrations in toad skin $(3 \mathrm{pmol}$ $\mathrm{g}^{-1}$ tissue); they found other non-peptide opioids in lower concentrations in the skin of rat and rabbit and, particularly, in bovine adrenal gland and brain $(0.05-0.13$ pmol $\mathrm{g}^{-1}$ ). Shortly afterwards, Goldstein and his group identified ${ }^{4}$ immunoreactive morphine in bovine hypothalamus and adrenal gland. They stressed that it was not clear whether the very small amount of morphine they had found was of endogenous or exogenous origin. Therefore, demonstration of biosynthesis of morphine would be decisive. This consideration is of importance because, in 1981, Hazum et al. found ${ }^{5}$ immunoreactive morphine in cow's milk and suggested a possible dietary source in animal fodder.

Last year, Spector's and Goldstein's groups both presented the results of their further analyses of endogenous nonpeptide opioids. Goldstein and his colleagues found ${ }^{6}$ that morphine and codeine are consistently present in extracts of bovine hypothalamus but variable in extracts of bovine adrenal gland and rat brain. Even then they still could not decide whether the action of these two morphinans is of an endogenous or exogenous nature or whether the morphinans are involved in brain function.

A few months earlier, Spector and colleagues had found ${ }^{7}$ free codeine and free morphine in extracts of rat brain. Because in the morphine biosynthesis of $P$. somniferum, norlaudanosoline, reticuline, salutaridine, thebaine and codeine are precursors of morphine ${ }^{8}$, Spector and colleagues decided to test whether intravenous injection of these morphinans would increase the free morphine content in the brain and other tissues of the rat (Table 1). It was not known whether the concentration of free morphine obtained by intravenous injection of codeine (16 vitro. This critical step of conversion is not present in rat brain or bovine adrenal gland. The authors point out that this finding is the first demonstration of the ability of an animal tissue to synthesize morphinans. This result strongly supports the hypothesis that the codeine and morphine found in mammalian tissue are of endogenous origin.

Although the concentrations in animal tissues of free endogenous codeine and morphine are much lower than the concentrations of opioid peptides (Table 2), some speculation on their significance may be permissible. There are two significant differences between the peptide and nonpeptide compounds ${ }^{10-12}$. First, morphine interacts almost exclusively with the $\mu$ opioid receptor, having a relative affinity of 0.98 (maximum $=1.0$; Table 2 ) but [Met]enkephalyl-Arg-Arg-Val- $\mathrm{NH}_{2}$ is less selective, having a relative affinity of 0.66

Table 2 Peptide and non-peptide opioid compounds with preference for the $\mu$-site

\begin{tabular}{cccc}
\hline Compounds & $\begin{array}{c}\text { Relative selectivity for } \\
\mu \text {-binding in } \\
\text { guinea-pig-brain }\end{array}$ & $\begin{array}{c}\text { Content } \\
\left(\mathrm{pmol} \mathrm{g}^{-1}\right)\end{array}$ & Tissue \\
[Met]enkephalyl-Arg-Arg-Val-NH & 0.66 & 6.5 & ${\text { bovine hypothalamus }{ }^{12}}^{\text {[Met]enkephalyl-Arg-Phe }}$ \\
Morphine & 0.60 & 112 & bovine hypothalamus $^{12}$ \\
& 0.98 & $0.03($ free $)$ & rat brain $^{7,9}$ \\
& & 0.7 (total) & \\
\hline
\end{tabular}

Selectivity index: $K_{\mathrm{i}}^{-1}$ for $\mu /\left(K_{\mathrm{i}}^{-1}\right.$ for $\mu+K_{\mathrm{i}}^{-1}$ for $\delta+K_{\mathrm{i}}^{-1}$ for $\left.\kappa\right)$.

pmol $\mathrm{g}^{-1}$; Table 1 ) is high enough to exert an agonist effect on the $\mu$-opioid receptor. Spector and his colleagues have now shown ${ }^{9}$ that free morphine and codeine are only small fractions of the sum of free and sulphate-conjugated compounds. In the rat brain, free morphine is $0.03 \mathrm{pmol}$ $\mathrm{g}^{-1}$, whereas the mean of total morphine is $0.7 \mathrm{pmol} \mathrm{g}^{-1}$ and that of total codeine is 1.2 pmol $\mathrm{g}^{-1}$.

These data indicate that it is essential to investigate whether there are in animal tissues mechanisms which convert the non-morphinan reticuline by intramolecular coupling to give the morphinan salutaridine, as occurs in $P$. somniferum. A full analysis of the fact that this conversion can take place in animal tissue is reported in the paper by Goldstein's group in this issue ${ }^{2}$. These authors produce convincing evidence that in rat liver reticuline can be converted to the morphinan salutaridine both in vivo and in

Table 1 Morphine concentration $\left(\mathrm{pmol} \mathrm{g}^{-1}\right.$ ) in some rat tissues after intravenous injection of saline or three morphinans (from ref. 7)

\begin{tabular}{ccccc}
\hline Tissue & Saline & $\begin{array}{c}\text { Salutaridine } \\
\left(31 \mathrm{nmol} \mathrm{g}^{-1}\right)\end{array}$ & $\begin{array}{c}\text { Thebaine } \\
\left(10 \mathrm{nmol} \mathrm{g}^{-1}\right)\end{array}$ & $\begin{array}{c}\text { Codeine } \\
\left(17 \mathrm{nmol} \mathrm{g}^{-1}\right)\end{array}$ \\
Brain & 0.026 & 0.059 & 0.096 & 16 \\
Liver & 0.011 & 0.136 & 0.150 & 115 \\
Intestine & 0.017 & 0.099 & 0.112 & 182 \\
\hline
\end{tabular}

Conversion to free morphine is much less with salutardine or thebaine than with codeine. at the $\mu$-receptor and of 0.31 at the $\kappa$ receptor, and [Met]enkephalyl-Arg-Phe is also less selective, having a relative affinity of 0.60 at the $\mu$-receptor and of 0.36 at the $\delta$-receptor. Second, the enzymatic stabilities of non-peptide and peptide opioids interacting with the $\mu$-receptor are also very different. Most of the peptide opioids are sensitive to the degrading action of peptidases, the exception being $\beta$-endorphin; in contrast, morphine is much more stable. We still know very little about the physiological role of endogenous morphine and codeine and their correlation with the functions of opioid peptides.

1. Kosterlitz, H.W. Nature 317, 671 (1985).

2. Weitz, C.J., Faull, K.F. \& Goldstein, A. Nature 330 674-677 (1987)

3. Oka, K., Kantrowitz, J.D. \& Spector, S. Proc. natn. Acad. Sci. U.S.A. 82, $1852(1985)$

4. Goldstein, A. et al. Proc. natn. Acad. Sci. U.S.A. 82, 5203 (1985).

5. Hazum, E. et al. Science 213, 1010 (1981)

6. Weitz, C.J., Lowney, L.I., Faull, K.F., Feistner, G. \& Goldstein, A. Proc. natn. Acad. Sci. U.S.A. 83, 9784 (1986).

7. Donnerer, J., Oka, K., Brossi, A., Rice, K.C. \& Spector, S. Proc. natn. Acad. Sci. U.S.A. 83, 4566 (1986)

8. Kirby, G.W. Science 155, 170 (1967)

9. Donnerer, J. et al. J. pharmac. exp. Ther. 242, 583 (1987).

10. Goldstein, A. \& James, I.F. Molec. Pharmac. 25, 343 (1984).

11. Kosterlitz, H.W. Proc. R. Soc. B225, 27 (1985)

12. Sonders, M. \& Weber, E. J. Neurochem. 49, 671 (1987).

H.W. Kosterlitz is Director of the Unit for Research on Addictive Drugs, University of Aberdeen, Marischal College, Aberdeen AB9 IAS, UK 